\title{
Environmental Casualties Due to State Policy in Indonesia's National Development (A Portrait of Jatigede Indigenous People Struggle)
}

\author{
MELLA ISMELINA FARMA RAHAYU \\ Universitas Tarumanagara Jakarta \\ Email : mellaismelina@yahoo.com
}

\author{
ANTHON F. SUSANTO \\ Universitas Pasundan Bandung \\ Email : Anthon.aiki@gmail.com
}

\begin{abstract}
State policy in the environmental development causes positive impact either on humans or environment in which both the humans and the environment becomes the causalities of the environment. This portrait occurs to the Jatigede people where the construction of the reservoir causes social, economic and environment problems. The problem is also worsened by the laws that do not on the people and the environment's side where the laws strongly take the environmental utilization side rather than the environmental function preservation and social welfare's side.
\end{abstract}

Keywords: Environment, Causalities, Policies, Indonesia.

\section{Introduction}

The characteristic of environmental law development in Indonesia is apart from the state policy that strongly orients toward the state laws and regulations, and policy which have top down quality so that its environmental management method undertaken is regulated and supervised. The state makes many laws and regulations on the environment to be obeyed by the people and conducts the supervision over their obedience. In this case, the state has domination over the development and its regulations.

The condition is worsening by the state's perspective on the development undertaken which orients toward anthropocentric paradigm, where the development undertaken is only for humans interest while it neglects the environmental interest so it results discrimination against the justice where the ecology is neglected.

Such oriented environmental development causes non-participative and holistic environmental policymaking as well as abandoning the values of local wisdom. Indigenous people become marginalized within the development undertaken. They are no longer having an access toward their environment and natural resources. The development is not environmentally friendly and unconcern on the values of local wisdom that impact on the people and the environment. In this matter, it can cause the vanishing of the local wisdom (Steny, 2009). 
The environmental development policy that impacts on the ecology, social and economic has been perceived by the local people who live near the Jatigede reservoir. The people suffer the losses by death of various ecosystems close to the reservoir where the people depend on the environment. The relationship between humans and their environment is always unique, besides the geographical dependency that the people's life depends on environmental ecosystem so that their daily life practically relies on the condition of the area. Furthermore, the people and their environment have unique inner connection or involve religious aspects within their life that their mutual relationship goes naturally as it is stated by Agus Purwadianto that the way ecologic systems organizes themselves has been tasted reliably to preserve the life on the earth planet (Agus Purwadianto, et al, 2004; 42-45). In the context of the construction of Jatigede reservoir on the next stages have eroded the unique aspects of the relationship between humans and their environment so that the people suffer severe losses.

It should be in the state (in the context of development) more prioritizes and orients for the sake of the environment and the people. The development is a strategic effort to develop the people and restore the environment in order that it is livable. The development policy should be pro toward the society. The losses that suffered by Jatigede people is not only physical loss but also the inner aspects as well as psychological aspects where the people do not feel protected and discriminated by the state. Within this condition, the alternative development is necessary to undertake, that is by carrying out an approach to the victims by paying attention to their needs and the values of local wisdom and their environment which leads to the effort to create the equality between social and ecological justices.

The paper criticizes the state policy in the construction of Jatigede reservoir which impact on the local people's social, economic, environment and ecological life even more it has potential damage toward the environment globally.

\section{State Policy and Development}

The humans and the universe are two entities that cannot be separable. Humans as microcosms and the universe as the environment where they live is macrocosm. Between the two of them interact each other, connect and cannot be separated. In this contemporary era, the relationship between humans and the environment is still discussed even it becomes global issue. The environmental problems in the $21^{\text {st }}$ Century appear due to the humans' ability to master of the nature with the result that they exploit most of it for the sake of their needs. On the other hands, it is due to the inadvisable and not environmentally friendly development and application of the science and technology.

Natural resources and environment are mostly posited as the target of a science which is exploited. Science and technology have to develop continuously for the advancement of human life. Science and technology should be applied for the humans' benefits. Humans' needs always evolve and have to be met; most of their needs are provided by the nature. By looking at this reality, the environmental problems are getting complicated. The existence of tug-of-war between the aspects of humans' needs the way how to perceive the environment; and the ideal situation of how people treat the environment. The problems are very complex but whether they want it or not they have to observant and are wise to understand the problems.

The efforts which undertaken by the state in relation to the environmental preserve and management policy do not see the opportunities of the local wisdom yet which it has religious-cosmic relation so that the existing environmental law development policy results an environmental management and development systems which are non-participative and holistic. The condition causes the law to be unable to identify and overcome the environmental problems in the society.

Jamie Davidson and David Henley in their edited introductory book state that the repression due to the development agendas which disfavor the indigenous people is one of the factors of the awakening of the contemporary indigenous people movement in Indonesia. Another factor is a legacy of customary law 
studies from the colonialism era, the openness which exists after the New Order, as well as the strengthening of indigenous people movement on the global scale (Davidson, Henley, and Moniaga, 2010). People (local) become the object of the development which can be seen in various policy and regulation laws which are made since the past time up until now, often create discriminatory treatment. For instance, local people live in the border of forest are seen as the threat of the investment. People who live near the reservoir often be seen as causing the trouble for the development.

It happens because the development do not concern on the conservation rules and it is strengthened by the concept of Cartesian worldview which tends to be anthropocentric that is placed human's interest as the only main consideration in the development (Oekan S. Abdullah, 2002:9). Beginning with that perspective, then an opinion elaborates that between the development and environment are contradictory where the environment will detain the development and in contrast the development will damage the environment. That condition causes a dichotomy between economic and environmental problems, development and society. The effect of the dichotomy is that people and environment are sacrificed for the development.

\section{People and Environment as Development Causalities}

The development of environmental law within Indonesian which is supported by western perspective is getting industrial and consumptive (developmentalism), (Schoorl:1980) and tends to be anti-ecological as it is explained by Fritjof Capra (2004:29) "excessive approach toward scientific method and rational analysis thought have generated anti-ecological attitude".. "economic development (consumptive) and infinite technology cause natural disruptive, and gradually will cause a great damage" or what Gunnar Myrdal says that if "theories and concepts of western development are applied will result serious consequences (Slamet Sutrismo, 2004: 100).

Environmental law development policy then just gives benefits and takes ply groups of people's sides or stakeholders, and will cause many victims, especially weak marginal people are getting marginalized. Some of the example cases are the costal damage in Cirebon, Lapindo mud in Sidoarjo, coastal ecosystem damage in Jakarta.

The constructions of skyscraper buildings and green houses cause negative effects for the people's life. The failure of reclamations in some mining areas in Kalimantan, floods and other cases that cause marginal people are getting aggrieved and become the victims of the environmental development law policy that do not take the people and environment's interests side.

In the politics of law character, the main problem faces by the people in the development are: first, (local/indigenous) people are faced against the procedures of complicated acknowledge of law so their existence and territory are depending upon formal mechanism. This case presents on one side of setting trends of the people (local/indigenous appears within the legalization but the implementation is done halfheartedly); second, violence and crime which are carried out toward the indigenous people who defend and fight for their right over their land and natural resources; third, tenured conflict that is related to the land tenure and ownership either at inside or at outside the forest areal. Forth, development program which still partially embraces the indigenous people.

It is because indigenous people are not the main subject of the development yet to develop the country. Fifth, the decision making problem which is related to the indigenous land used is conducted by central and local government in the form of permission without approval of indigenous people. Not to mention their position particular group in their society, i.e. indigenous female's role in the decision making process. The mechanism of Free prior and Informed consent (FPIC) is an important procedure adopted by Indonesia to ensure the independency and protection of people's rights. 


\section{Legal and Power Relation in The Construction of Jatigede Reservoir ${ }^{1}$}

The polemic of Jatigede reservoir construction has long been happening and the impacts of the construction are hit by the indigenous people near the reservoir. ${ }^{2}$ this paper discusses Jatigede reservoir as the study case since the effects of the construction are not potentially only for the local people but also potentially have national and even global impacts. Jati gede is a community of Kabuyutan. Kabuyutan is a sacred place that has historical, cultural and spiritual values for the people. Community of Kabuyutan is a community whoc concerns on the conservation of natural resource functions, local culture, cultural heritage sites and noble value of Indonesians' spiritualism.

The reason for the public refusal to Jatigede Reservoir construction is the construction site on which the epicenter of the earthquake and active tectonic plate baribis located that may dangerously break the reservoir. According to the results of research conducted by academicians of the Faculty of Geology Universitas Padjadjaran, it is found that the reservoir is a risky project as it is close to the epicenter of the earthquake and there is an active fault below that passes a fracture zone on the earth that experienced shifts of which affect the erosion of Cimanuk watershed leading to Jatigede, thus, Jatigede is not feasible to construct.

This construction will cause cultural and spiritual problems as several Cultural Heritage Sites are also in danger of being damaged and drowned. Twenty five archaeological sites of ancient tombs attached to the coordinates, cannot be relocated or moved. Furthermore, in the view of forestry and environment side there are 1389 hectares of state-owned forest with 800.000 trees cut down because of its location in front of the reservoir. Seeing from the natural resources and rich biodiversity of Jatigede inundation, the area is very good as it consists of Agricultural potentials where 2050Ha Rice Field with the chance of twice until three times harvest.

Perceiving the sedimentation problem, the very high sedimentation flow predicted by DPKLTS is 16 Million tons per year that will shorten the span of the reservoir and PLTA hydro turbine. In addition, the construction of Jatigede reservoir may damage the social and spiritual order of society at Buhun Kabuyutan Cipaku Village. Economically, there are 16,000 householders who inhabit the reservoir's inundation area lost their homes and livelihoods. Similarly, there are potentials of agrarian conflict and 12,000 public complaints that have not been resolved. On the other hand, agricultural land downstream the reservoir is diminishing due to land conversion to factories, industries, housing, toll roads, airports, and so on.

Essentially, the construction of Jatigede reservoir has caused couple of problems including some dysfunctions of rivers, landscapes and submerges of native ecosystems, changes of hydrological cycle of river, loss of dwellings with no guarantee of better compensation, vanish of fertile soil and cultural heritage and historical sites. When the condition of forest is not good, it also occurs to the river. This condition is so-called no forest-no water-no future or in Sundanese Culture Wisdom known as leuweung ruksak-cai beak-manusia balangsak. Bad rivers can only be restored by restoring the condition of the forest in the watershed. The destruction of protected areas causes the destruction of water management system and the emergence of environmental and social disasters. Thus, it takes effort to restore and preserve the environment and its natural resources for the sake of sustainability of world civilization. In addition, it is necessary that state policy in development is aligned with economic, environmental and social concerns.

F. Budi Hardiman stated that conditional recognition has a subject-centric, paternalistic, asymmetrical, and monologue paradigm, such as: "State acknowledges", "State respects", "along ... in accordance with the principle of NKRI" which presupposes the great role of the state to define, acknowledge, legitimize, legitimize existence, as long as indigenous people are conquered under state regulation or in other words, "tamed" (Hardiman, 2006: 62). This paradigm does not conform to the principle of equality and autonomy existing in democracy. 


\section{Society's Efforts as Victims}

How can efforts be made by the society? The law has provided a model for them to be able to take strategic steps, especially when they become a victim of a biased development both for the people and environment. Several things that need to be done to protect the society (Yenni Widowaty, Fadia Fitriyanti, 2014), can be explained as follows:

a. The need of state's recognition of the right of the (local) people about their positions and conditions in living their lives to gain the comfort. The state should play an active role in protecting the society, environment and local wisdom;

b. Compensation for the society and Recovery of the Environment; Any act of a State or corporation that commits an act of pollution / law violation shall pay compensation and / or perform certain actions.

c. Strict Liability, any act of a state or corporation posing a serious threat to the society and environment is ultimately responsible for any loss occurs without the need to prove the element of error;

d. Right of Society Lawsuit; that the society is entitled to file a class representative's claim for its own interest and / or for the benefit of the society if it suffers losses due to pollution and / or damage of the environment. A lawsuit may be filed if there is a similarity of fact or event, legal basis, and type of claim among group representatives and members of the group.

e. Right of Environmental Organization Law. In implementing environmental protection and responsibility, environmental organizations are entitled to file lawsuits for the preservation of environmental functions.

\section{Conclusion}

The construction of Jatigede reservoir is a reflection of how state policy in development has caused victims both for society and environment. It has led to a high social cost and risk because its development is in the epicenter position of earthquake and active baribis tectonic plates. It is done when Cimanuk River is not maximal in the capacity and support for environment causing vulnerability of environmental function for preservation. Economically, the construction is only beneficial for a handful of people not for the whole part of surrounding society. It is supposed to be a lesson to us, about how important the role of society in environmental development is, though often regarded as unimportant. More serious development efforts in respecting the rights of the people should be put forward, therefore they must be pro-society, environment and local wisdom.

\section{References}

Agus Purwadianto, dkk (2004). Paradox Way; New Vision of Fritjof Capra on local wisdom and modern life, Teraju, Mizan, Bandung.

F. Budi Hardiman, (2006). Structural Position of nation Tribe and Relation between Nations in Nationality and Statehood in Indonesia (Viewed from Philosophical Perspective), Structural Relations of Indigenous Peoples, Ethnic Groups, Nations, and Countries (Viewed from Human Rights Perspective), Jakarta: Komnas HAM.

Fritjof Capra, (2004). Hidden Connection; Systemic strategy against New Capitalism, jalasutra, Jogyakarta.

Fritjof Capra, (2004). Turning Point of Civilization, Science, Society and revival culture, Bentang, Jogyakarta.

Mella Ismelina FR, (2010). dkk, Law-Based Environment Based Design Model (DAS) Religius-Cosmic According to Sundanese Culture Wisdom, Laporan Penelitian Hibah Bersaing DIKTI, (Bandung: Unisba 2010).

Oekan S. Abdoellah, (1980). Social responsibility of scientific society in managing future environment: Effots towards sustainable development, Program Pascasarjana Unpad, Bandung, 2002; Schoorl, Modernization, Penerbit Obor, Jakarta. 
Slamet Sutrisno, Krisis Pemikiran Modern \& Kawruh Jawa, dalam Agus Purwadianto, dkk (2004). New Vision of Fritjof Capra on local wisdom and modern life, Teraju, Mizan, Bandung.

Steny, Bernadinus. Steny, (2009). Politics of recognition of indigenous people: From colonial heritage to independent country, Jakarta: Jurnal Jentera Edisi Lingkungan.

Yenni Widowati, Fadia Fitriyani, (2014). Developing protection model against society as victim of environmental pollution and damage by corporation with restorative Justice Principle, Journal Media Hukum, Volume 21 No.1 Juni.
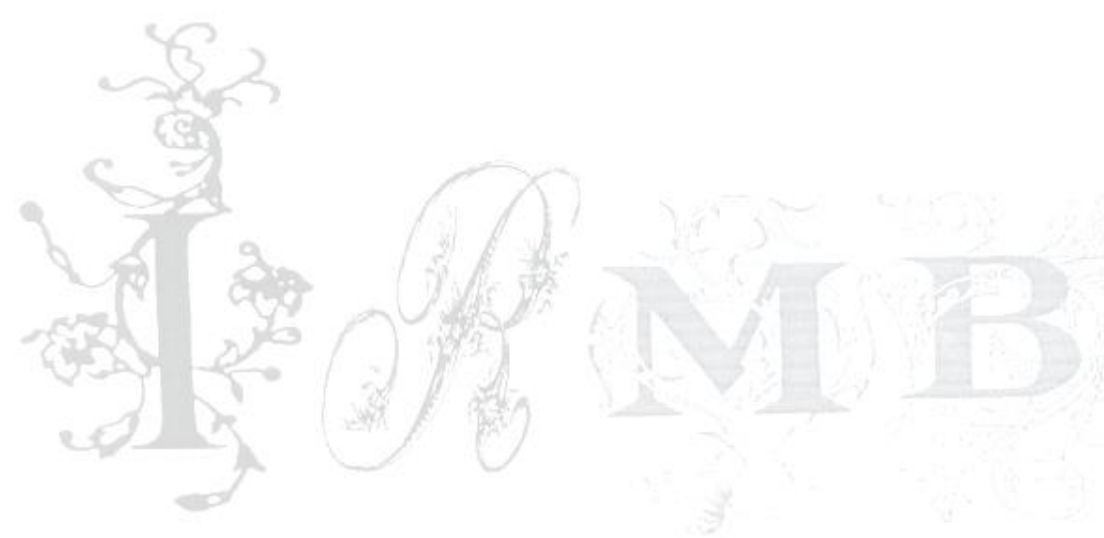